\title{
The Importance of Comprehensive Assessment of the Sexually Abused Child
}

\author{
Luz N. Colon-De Marti, MD \\ Thomas Jefferson University Hospital
}

Follow this and additional works at: https://jdc.jefferson.edu/jeffjpsychiatry

Part of the Psychiatry Commons

Let us know how access to this document benefits you

\section{Recommended Citation}

Colon-De Marti, MD, Luz N. (1985) "The Importance of Comprehensive Assessment of the Sexually Abused Child," Jefferson Journal of Psychiatry. Vol. 3 : Iss. 1 , Article 11.

DOI: https://doi.org/10.29046/JJP.003.1.007

Available at: https://jdc.jefferson.edu/jeffjpsychiatry/vol3/iss1/11

This Article is brought to you for free and open access by the Jefferson Digital Commons. The Jefferson Digital Commons is a service of Thomas Jefferson University's Center for Teaching and Learning (CTL). The Commons is a showcase for Jefferson books and journals, peer-reviewed scholarly publications, unique historical collections from the University archives, and teaching tools. The Jefferson Digital Commons allows researchers and interested readers anywhere in the world to learn about and keep up to date with Jefferson scholarship. This article has been accepted for inclusion in Jefferson Journal of Psychiatry by an authorized administrator of the Jefferson Digital Commons. For more information, please contact: JeffersonDigitalCommons@jefferson.edu. 


\title{
CHILD PSYCHIATRY
}

\section{THE IMPORTANCE OF COMPREHENSIVE ASSESSMENT OF THE SEXUALLY ABUSED CHILD}

\author{
LUZ N. COLÓN-DE MARTÍ, M.D.
}

\section{INTRODUCTION}

In the past few years public awareness of sexual abuse of children has increased, together with the recognition of its social, physical, and psychological effects (1). We must emphasize our role as diagnosticians in doing a comprehensive assessment of the sexually abused child. It is our professional responsibility to assess the general psychological status of the child before and after sexual abuse.

\section{CASE REPORT}

Alice, a seven-year-old girl, was brought to the Emergency Room after having been sexually abused by a stranger who broke into her house while her parents were absent. She was admitted to the Pediatric Service for surgical repair of severe vaginal lacerations. During her hospital stay she was seen by the Child Psychiatry Consultation and Liaison staff (2), who ascertained that Alice had evidence of unresolved psychological conflicts that were probably present before she was sexually abused, as well as having some of the most frequently observed reactions of the sexually abused child. A meeting was arranged with Alice's mother prior to her discharge, where it was agreed that Alice would continue in individual treatment.

A psychotherapeutic relationship with Alice was established through the use of her spontaneously made drawings. She used her drawings as a graphic expression of her worries and concerns. She manifested some of the frequently described behavioral reactions seen in children exposed to psychological trauma (3): nightmares (where the mother described her as if "she was pushing the sky with her hands and kicking with her legs") (4); scared to be alone, scared to sleep by herself, and scared of strangers. She expressed some concern about the healing of her vaginal lacerations. It was also through her drawings that Alice was able to discuss some of her prior emotional conflicts, for example, her reaction to the separation of her parents several years earlier. After three months of psychotherapy, Alice was able to work through her major post-traumatic stress symptoms. She continued in therapy because of preexisting conflicts. 


\section{DISCUSSION}

It is important to do a comprehensive assessment of the sexually abused child, exploring the pre-traumatic emotional status of the child, as well as the impact of being sexually abused. As is frequently seen in abused children and rape victims, Alice presented symptoms that met $D S M-I I I$ criteria for a post-traumatic stress disorder (5, 6). According to Sgroi, these children need psychotherapeutic help to address "impact issues" such as guilt, depression, low self esteem, poor social skills, repressed anger and hostility, impaired ability to trust, blurred role boundaries and role confusion, pseudomaturity with failure to accomplish developmental tasks, and self mastery and control (7). Sgroi also considered "the damaged goods syndrome" as one of the "impact issues," wherein because of the physical damage caused to the child he or she can come to believe that they were damaged. Alice sustained vaginal lacerations that she referred to in her first contact with the therapist. "I was bleeding from there," she said, pointing to her genital area. "It hurts . . but . . . it will get better; the doctor told me..."

Another important issue that needed to be addressed was the effect of Alice's hospitalization. Anna Freud has stated that hospitalization can be an emotionally hazardous event, not only because of the emotional reactions to the illness itself, but because the child is exposed to separation from his family, an event that may have a profound effect on the child's development (10). Through her drawings Alice was able to relate her most disturbing behavioral reactions and discuss "impact issues." DiLeo has stated that drawings are "one means of establishing a rapid, easy and pleasant rapport" $(8,9)$. In Alice's case they facilitated the establishment of a therapeutic alliance and psychotherapeutic treatment, as will be discussed in a separate communication.

The stress of sexual abuse creates a crisis, the severity of which depends on many factors, including how successful the victim had been in solving crisis situations in the past $(2,11)$. This is another reason supporting the need for the comprehensive assessment of the sexually abused child. The recovery from such a traumatic experience can be compromised, as Burgess and Holmstrom found in their follow-up study of rape victims, by the impact of life stresses prior to the traumatic event (12). Some sexually abused children, like Alice, need to address those pre-traumatic issue that could further compromise their psychological and social development. Anna Freud wrote:

The whole personality of the child should be scrutinized for certain general characteristics which are of possible significance for predicting the chance for spontaneous recovery and reaction to treatment ... (13)

Our role is thus defined as one of doing a comprehensive and clinically meaningful assessment that includes the recognition of factors and processes that may effect psychological growth. The psychiatric evaluation, therefore, should include an assessment of the emotional state of the child before and after being sexually abused. Moreover, it is our responsibility to facilitate their recovery not only from their traumatic experience, but to promote their general emotional development as well. 


\section{REFERENCES}

1. Seidl T, Paradise JE: Child sexual abuse: effective case managment by a multidisciplinary team. Res Staff Phys 30: 48-51, 1984

2. Ravenscroft: Psychiatric consultation to the child with acute physical illness and hospitalization. Psych Ann 12: 1065-1073, 1982

3. Terr LC: Psychic trauma in children: observations following the Chowchilla school bus kidnapping. Am J Psych 138: 14-19, 1981

4. Fenichel O: The Psychoanalytic Theory of Neurosis. New York, Brunner/Mazel, 1983

5. Burgess AW: Rape ... Crisis and Recovery. Maryland, Robert Brady, 1979

6. Green A: Child abuse, dimension of psychological trauma in abused children. $J$ Am Ac Ch Psych 22: 231-237, 1983

7. Sgroi S: Handbook of Clinical Intervention in Child Sexual Abuse. Toronto, Lexington Books, 1982

8. DiLeo JH: Interpretation of Childrens Drawings. New York, Brunner/Mazel, 1983

9. DiLeo JH: Young Children and Their Drawings. New York, Brunner/Mazel, 1970

10. Freud A: Role of body illness in the mental health of children. Psychan St Ch 7: 149-152, 1962

11. Lindemann E: The meaning of crisis in individual and family. Teachers College Record 310: 1956-7

12. Burgess A, Hoslstrom WLLL: Recovery from rape and prior life stresses. Rs Nurs Health I: $165-174,1978$

13. Freud A: Assessment of childhood disturbances. Psychoan St Ch 7: 149-158, 1962 